\title{
The Reconstruction of Public Information Dispute Resolution as the Effort in Realizing Substantive Justice in Indonesia
}

\author{
Kadek Cahya Susila Wibawa*, Aju Putrijanti \\ Diponegoro University, Semarang, Indonesia
}

Received: $25 / 08 / 2020$

Accepted: 18/10/2020

Published: 20/03/2021

\begin{abstract}
The right to information is a human right as derogable right. Fulfilment of the right to information often leads to information disputes with Information and Documentation Management Officer (IDMO) as administrative officials who are given the task of managing information and documentation. Information dispute resolution becomes important to be resolved immediately because it is related to fulfilling a sense of justice and fulfilling the right to information for the community. The Establishment of the Government Administration Act (GA Act) causes the dualism of information dispute resolution. Article 53 of the GA Act will be the basis for resolving information disputes in the administrative court domain, while the Public Information Officer/PIO Act is the basis for resolving information disputes within the Information Commission domain. This dualism needs to be resolved to ensure legal certainty for the government and society as Justicia Belen. The development of dispute resolution reconstruction of information is conducted by strengthening information dispute resolution in non-litigation. Ideal information dispute resolution should be resolved first through administrative remedies (objections and administrative appeals) and through the Information Commission. The court becomes the ultimum remedium in resolving a dispute. Therefore, strengthening the Information Commission in terms of development, finance and authority is one way to strengthen the resolution of information disputes outside the court.
\end{abstract}

Keywords: Information Commission; Public Information Dispute; Information Openness

\section{Introduction}

Basically, a state in its realization as the government has the duty to realize the goals of the country by providing public services. The government (state) is obliged to build public trust in public services and the state needs to strive for an effort to improve the quality and guarantee the provision of public services in accordance with general principles of good governance and corporation [1]. Indonesia has stipulated Law No. 25 of 2009 concerning Public Services (PS Act) as a legal basis for the government to realize optimal and excellent public services. One of the supporting indicators of the successful implementation of public services by the government is by applying the principle of maximum information disclosure. Article 4 of Law No. 25 of 2009 concerning Public Services, states that the implementation of public service is based on; legal certainty; equal rights; the balance of rights and responsibilities; professionalism; participatory; equality of treatment (non-discriminatory); openness; accountability; special facilities and treatment for vulnerable groups; punctuality; speed, convenience, and affordability. Furthermore, in the Elucidation of Article 4 letter $h$ of Public Services/PS Act, it states that each service recipient can easily access and obtain information about the desired service. Based on the law above, public services are closely correlated with the ease of accessing and obtaining information or correlated with public information disclosure.

Rights to information openness is a part of human rights that is derogable right. Golwal \& Kalbande stated that, "right to know is also closely linked with other basic rights such as freedom of speech and expression and right to education. It is an attribute of liberty" [2]. Recognition of the right to information disclosure as part of human rights is expressly regulated in the Universal Declaration of Human Rights (UDHR), which was declared by the United Nations on December $10^{\text {th }}, 1948$. In line with this law, Indonesia has enacted Law No. 14 of 2008 concerning Public Information Openness (PIO Act) on April 30 ${ }^{\text {th }}$, 2008. PIO Act (Public Information Openness Act) in principle is expected to guarantee the right of the public to obtain public information; regulate state obligations; and guaranteeing private and public participation in the delivery of public services. Adji Achmad Rinaldo Fernandes \& Jhon Fresly stated that [3]:

The successful performance of good public services is largely determined by the involvement and synergy of the three main actors-government, society, and the private sector. In the administration of thegovernment, government apparatus is one of the important actors in control of the process of good

Corresponding author: Kadek Cahya Susila Wibawa, Diponegoro University, Semarang, Indonesia. E-mail: kcswibawa.undip@gmail.com 
governance. The involvement of the government apparatus in supporting the success of governance is largely determined by understanding the concept of good governance and excellent experience with bureaucracy and government bureaucracy.

According to Public Information Openness Act, people have the right to obtain public information from the government. The governance of public information does not only allow people to access government information but also enables them to actively participate in the policy-making process [4]. Public information can be requested by the public in this case as an applicant for public information to the Information and Documentation Managing Officers (IDMO) as long as it meets the formulation of Article 2 of the Public Information Openness Act that the requested information is not confidential information and it is excluded as public information in the Public Information Openness Act or constitutes information that is if opened can actually damage the greater interests [5]. Public requests that are not responded to by the Information and Documentation Managing Officers (IDMO) can be submitted to the supervisor of the Information and Documentation Managing Officers. Filing an objection is the beginning of a dispute (conflict) between the applicant for public information and public bodies.

Article 37 paragraphs (1) and (2) of the Public Information Openness Act in conjunction with Article 35 paragraph (1) of the Public Information Commission Regulation Number 1 of 2010 concerning Public Information Service Standards regulates that: public information applicants file objections or parties who receive dissatisfied power of attorney with the decision of the IDMO superior have the right to submit a Public Information dispute resolution to the Public Information Commission no later than 14 (fourteen) working days from the receipt of the IDMO superior's decision.

In this stage, the problem will arise if the regulation is related to Law No. 30 of 2014 Regarding Government Administration (GA Act). In the event that the IDMO supervisor does not provide an answer to the objection raised by the public information applicant, it will be possible to have two scenarios, as follow: (1) The information applicant can submit a public information dispute resolution to the public information commission for not responding to the objection filed by the IDMO supervisor; (2) Based on Article 53 of the GA Act that: adheres to the principle of positive fiction, the petition (community) which is not followed up by government bodies and/or officials with decisions and/or actions, is considered legally granted (positive fictitious). With this second scenario, the state administrative court has the authority to resolve the dispute. This condition has resulted in a legal dualism in the settlement of public information disputes and empirically the dualism will cause public confusion in seeking justice in the field of public information disputes in Indonesia.

One other problem that is also faced in the settlement of public information disputes is related to the post-decision of the public information dispute, such as the execution of the decision. Decisions on public information disputes, both through the court and the Information Commission, proved to be very difficult to ask the public body as the respondent to comply with the decision. Even the PIO Act does not contain norms regarding the execution of public information disputes. Based on the case, this paper aims to describe the urgency of resolving public information disputes; layout the current public information dispute resolution construction; and reconstruct the ideal dispute resolution of public information in an effort to realize substantive justice in Indonesia.

\section{Research Method}

This research combines non-doctrinal legal research and doctrinal legal research. Non-doctrinal legal research relies on the constructivism paradigm. Related to doctrinal legal research, this research uses a philosophical approach, conceptual approach, and regulatory approach by using the secondary data. In the statutory approach, an analysis is carried out on the 1945 Constitution of the Republic of Indonesia, PIO Act, GA Act, Law No. 14 of 1985 concerning the Supreme Court (with amendments), Law No. 48 of 2009 concerning Judicial Power, Law No. 5 of 1986 concerning State Administrative Court (SAC Act), Supreme Court Regulation No. 2 of 2011, and Information Commission Regulation Number 1 of 2013.

Analysis of the results of studies to answer the issues was conducted using a qualitative constructive approach. Qualitative research is research that is used to investigate, describe, explain, discover the quality or features of social influence that cannot be explained, measured, or illustrated through a quantitative approach [6]. Constructive in this research means that the analysis is not just a description but also at an interpretive stage and ultimately undertakes a reconstruction related to dispute resolution of public information in Indonesia.

\section{The Urgency of Public Information Dispute Resolution}

Public information openness is very important and it relates to realizing the open state implementation. The right to public information is very important because the community needs to be involved in governance, development, and public services to realize good governance. Public participation or involvement does not mean much without guaranteeing the disclosure of public information [7].

Community involvement in governance, development, and public services often results in conflict or dispute. Conflicts and disputes always occur in the association of human life. Nia Kurniati stated that "the term conflict and dispute contained an understanding of differences in interests between the two or more parties, but between the conflict and the dispute both could be distinguished" [8]. Conflict may be defined as a struggle or contest between people with opposing needs, ideas, beliefs, values, or goals. Conflict on teams is inevitable; however, the results of the conflict are not predetermined [9]. A conflict changes or develops into a dispute when the aggrieved party has expressed dissatisfaction or concern, either directly to the party that is considered to be the cause of the loss or to another party [8].

Article 1 Number 5 of the Public Information Openness Act states: public information disputes occur between public and users of public information relating to the right to obtain and use information based on legislation. Basically, disputes or conflicts between information managers and requesters of information are very likely to occur due to several reasons, namely: (1) Disputes regarding information that may be accessed with which may not be accessed; (2) Disputes regarding the refusal of public bodies to provide the information requested by the requesting party for public information; (3) Disputes regarding the delay of public bodies to provide the information requested by public information applicants; and (4) Disputes regarding the number of costs 
imposed by public bodies for costs to be paid by an applicant for public information [10].

Based on 2010-2019 data, it is recorded that the Information Commission has received 2928 requests for resolution of public information disputes and state administrative courts based on 2015-2019 data received 51 requests for resolution of public information disputes; with details of data per year below:

Table 1. Number of Settlement of Public Information Disputes Request

\begin{tabular}{|c|c|c|}
\hline \multirow[b]{2}{*}{ Year } & \multicolumn{2}{|c|}{ Number of Public Information Dispute } \\
\hline & $\begin{array}{l}\text { Information } \\
\text { Commission }\end{array}$ & $\begin{array}{c}\text { Supreme Court } \\
\text { (State Administrative Court) }\end{array}$ \\
\hline 2010 & 76 & - \\
\hline 2011 & 419 & - \\
\hline 2012 & 324 & - \\
\hline 2013 & 377 & - \\
\hline 2014 & 1354 & - \\
\hline 2015 & 71 & 11 \\
\hline 2016 & 64 & 14 \\
\hline 2017 & 120 & 13 \\
\hline 2018 & 60 & 7 \\
\hline 2019 & 63 & 6 \\
\hline Total & 2928 & 51 \\
\hline
\end{tabular}

Source: Processed from Annotation of the Public Information Openness Act and the Supreme Court Report.

In 2018, there were 682 requests of public information dispute that had not been solved Information Commission. The number of unsolved cases increased in 2019 of 63 cases. It brought the total number of unsolved cases to 2019 of 745 cases. Based on these data, there are still quite many cases of public information disputes that have not been resolved, either by the Information Commission or by the Supreme Court. Settlement of public information disputes is absolutely necessary because: (1) Settlement of public information disputes is to realize the value of justice for the parties to the dispute, in this case, the public as applicants for public information with the government (public agencies/officials); (2) Settlement of public information disputes as a mechanism guaranteeing the fulfillment of the rights of the public to the public information. This is important because the right to public information is one of the human rights constitutionally granted by the State through the 1945 Constitution of the Republic of Indonesia; (3) The government requires legal certainty related to the substance in dispute, whether included as information that is opened or does not need to be opened to the public. This certainty is needed to continue the administration of government, development, and public services; and (4) Preventing misuse of authority of public bodies and negligence of obligations of the public. Eko Noer Kristiyanto stated: settlement of public information disputes means the fulfillment of the right of everyone to obtain information, thus, it is relevant to improve the quality of services and also involve the community in the process of making public decisions [7]. Based on this case, dispute resolution is to realize justice for the Justicia Belen (public information applicants) and for information management; and the realization of good governance. Therefore, the resolution of public information disputes is a matter that can't be postponed to be resolved.

\section{The Construction (Dualism) in Settlement of Public Information Disputes in Indonesia}

Based on Public Information Openness Act and Government
Administration Act, the settlement of public information disputes in Indonesia basically can be solved in two ways, namely: Information Commission and State Administrative Court (SAC/PTUN). Both of these pathways can be taken if there has been an attempt to file an objection in advance from the public information that applies to the IDMO supervisor. In the event that the IDMO supervisor responds to the objection, if it is still not satisfied, the information applicant can submit a dispute resolution to the information commission. However, if the IDMO supervisor does not respond to the objection, then based on Article 53 of the GA Act, then the next settlement if the applicant is not satisfied can file a lawsuit to the state administrative court.

First, the Settlement of Public Information Disputes through Information Commission Article 38 Section (1) Public Information Openness Act states that The Information Commission solves public information disputes through mediation and/or non-litigation adjudication no more than 14 (fourteen) working days after receiving requests for resolution of public information disputes. Articles 39 and 40 of the Public Information Openness Act states that decisions of the Information Commission originating from an agreement through mediation are final and binding, and dispute resolution through mediation is the choice of the parties and is voluntary.

Article 42 of the Public Information Openness Act stipulates that the resolution of public information disputes through nonlitigation adjudication by the Information Commission can only be taken if the mediation attempt is declared unsuccessful in writing by one of the parties to the dispute, or one of the parties to the dispute withdraw from the negotiations. With regard to the decision of the Information Commission on non-litigation adjudication, legal remedies can be made in the form of filing a lawsuit through the state administrative court if the sued person is a state public body or the filing of the claim is made through a district (general) court if the sued is a public body other than the state public or private-public (vide Article 47 of the Public Information Openness Act).

Another legal effort after through state administrative court or district (general) court is filing an appeal to the Supreme Court. Based on this case, the process of seeking justice in public information disputes through the door of The Information Commission does not recognize appeals in the state administrative high court or the high court. The cassation process according to the Public Information Openness Act is carried out without an appeal. Based on Article 23 of Law No. 48 of 2009 concerning Judicial Power and Article 43 of Law No. 14 of 1985 concerning the Supreme Court (Supreme Court Act), it is possible to submit an appeal without prior appeal as long as this matter is regulated or determined by law. Related to the reasons for cassation, the Public Information Openness Act only mentions the reason a person filed an appeal because they did not receive a state administrative court decision or a district (general) court [7].

Second, the Settlement of Public Information Disputes through State Administrative Court. Law No. 5 of 1986 of State Administrative Court as a legal basis for the court to operate under the Supreme Court, with specific competence states: the absolute competence of the court is to investigate, decide and settle the administrative dispute, include the staffing dispute [1]. The state administrative court has the authority to decide administrative disputes related to the provisions (beschikking) issued by the state administration official, in the case of a case being submitted to a state administrative court which is the object of any claim by the 
plaintiff is related to the issuing beschiking by state administration officials who are considered detrimental to one party or even many parties. With the existence of the Public Information Openness Act and Supreme Court Regulation No. 2 of 2011, the authority of the state administrative court has also increased, especially in adjudicating public information disputes [10].

The state administrative court becomes the first path for settlement of public information disputes if the public information applicant submits a lawsuit based on Article 53 of the Government Administrative Act (without going through the Information Commission) and may become a further legal remedy if previously the information dispute has been tried through the Information Commission.

There is different terminology between Article 47 of Public Information Openness Act and Supreme Court Regulation No. 2 of 2011, in terms of objection and lawsuit at the time of the settlement of a public information dispute to the state administrative court (general) court. The Public Information Openness Act uses the term lawsuit in resolving information disputes to the court, whereas Supreme Court Regulation No. 2 of 2011 uses the term objection. This will overlap with the term objection submitted by the public information that applies to the IDMO supervisor.

Public Information Openness Act and Supreme Court Regulation No. 2 of 2011 are not familiar with the term appeal to the state administrative court or district (general) court decisions. The next legal remedy is to submit a cassation to the Supreme Court. The problem is the information applicant who filed a lawsuit to the state administrative court without going through the Information Commission channel, whether it is also subject to the provisions of the Supreme Court Regulation No. 2 of 2011 and the Public Information Openness Act or it is subject to the State Administrative Court Act. This becomes unclear or out of sync because the State Administrative Court Act states that legal remedies after submitting a lawsuit to the state administrative court are appeals to the state administrative high court. Thus, legal efforts from the beginning through the state administrative court, only cassation to the Supreme Court.

Another problem is about public information disputes with non-state public agency petitioners, the first settlement after filing an objection to the IDMO superiors can only be reached through the Information Commission (not through a state administrative court or district/general court). That is because the respondent is not included in the scope of the state administration officials. Thus, the basis of Article 53 of the Government Administration Act can't be applied in this case. In brief, the flow or construction of public information dispute resolution in Indonesia can be described in Figure 1.

Figure 1. The Scheme of Information Dispute Settlement in Indonesia Source: Data Processed based on Public Information Openness Law and Government Administrative Law

The dualism of settlement of public information disputes is caused as a result that there is no explicit regulation in Public Information Openness Act that objections and dispute resolution in Public Information Openness are prerequisites for filing legal remedies through state administrative courts (in adjudicating public information disputes involving state public bodies). This inconsistency is a natural thing considering that the GA Act was passed after the PIO Act. Thus, the legislators of the Public
Information Openness Act may not take into account that factual

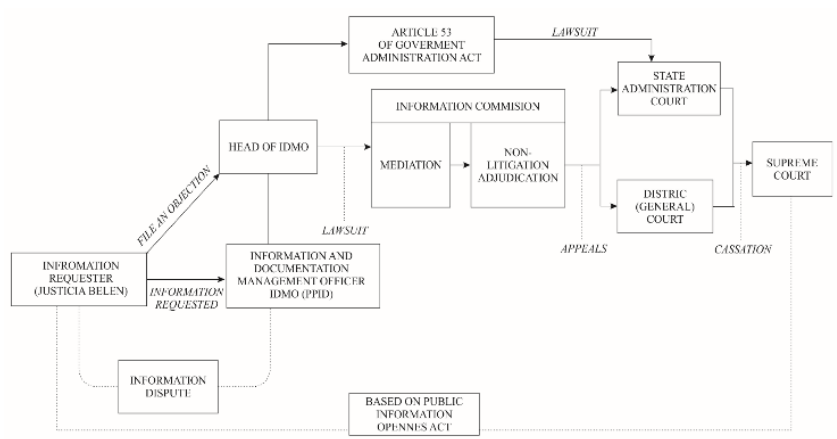

actions of state public bodies can be subjected to claims in state administrative courts (vide Article 1 number 18 of the Government Administrative Act).

\section{Result}

Naomi Creutzfeldt \& Ben Bradford argued, "Justice Systems vary considerably and each jurisdiction has its own approach to defining how people can legally resolve disputes. This provides both challenges and opportunities for access to justice." Furthermore, Naomi Creutzfeldt \& Ben Bradford also added "The concept of access to justice has a number of nuances; however, on a principal level the aim is to ensure effective independent dispute resolution mechanism." [11].

In connection with the settlement of public information disputes in Indonesia, it is necessary to inventory several things that become weaknesses in the resolution of information disputes in Indonesia, such as (1) Dualism of information dispute resolution paths, namely: through the Information Commission (vide Public Information Openness Act) and through the State Administrative Court (vide Government Administrative Act); (2) Weak position and nature of the relationship of the Information Commission. This can be seen from the position of the Regional Information Commission that is still under the service or regional government agencies, even though Article 23 of the Public Information Openness Act states: The Information Commission is an independent agency that functions to carry out this law and its implementing regulations establish technical guidelines for Public Information service standards and resolve public information disputes through mediation and/or non-litigation adjudication.

Another weakness is the Information Commission the nature of the working relationship between the Central Information Commission and the Information Commission in the provinces and districts/cities is not hierarchical in nature [12]. The next reality is related to the inability to execute decisions made by the Information Commission during mediation and non-litigation adjudication; (3) On the litigation track, no appeal is available (advanced court) if the disputing party is not satisfied with the decision of the first court (general court or administrative court). Legal remedies against the verdict of the first instance court are only appealed to the Supreme Court.

The development model of the settlement of public information disputes needs to be conducted immediately. It is substantially to provide legal certainty and fulfillment of the value of justice for the parties to the dispute. The current model of information dispute resolution is considered not able to fulfill or realize substantive justice for justice seekers in the field of public 
information.

First, strengthening administrative legal efforts (Objections and Administrative Appeals) as the First Line of Information Dispute Resolution. The administrative legal effort is legal protection efforts given to individuals or legal entities in dispute with state administrative bodies or officials, where the implementation still involves the government. In the state administrative justice system, there are two ways to resolve disputes in the state administrative court. For state administrative decisions that provide administrative-legal remedies, the resolution of the dispute must be done through administrative legal measures (objections and administrative appeals). If the state administrative decision does not recognize administrativelegal remedies, a claim can be filed directly to the state administrative court.

In the context of public information disputes, ideally, the parties to the dispute must first seek a solution through administrative-legal measures (objections and administrative appeals). Hermanto \& Sudiarawan stated that the objection can be submitted to the agency that issued the decision or agency that is vertically higher [13]. Objection may be found in all fields and in every agency authorized to make decisions.

Article 48 paragraph (2) of the State Administrative Court Act stipulates Procedure for objection is that the settlement of the State Administrative Decree must be carried out by the State Administration Agency or Officer who issued the Decree. Siti Soetami quoted by Bagus Hermanto \& Kadek Agus Sudiarawan explained, "Administrative appeals are if the resolution is carried out by a supervisory agency or other agency from the issuing the relevant decision" [13]. Administrative appeals can be made to a higher administrative body or a committee that was formed specifically for the purpose of resolving a dispute. The decision of the higher body or special committee can then be submitted to the next stage of the request for dispute resolution.

Optimization of administrative-legal efforts needs to be done to reduce the pile of cases in court. This is because there are many burdens of the court, especially the Supreme Court. Therefore, efforts to resolve dispute resolution or dispute resolution outside the court need to be minimized. Regarding public information disputes, efforts to resolve through objections to the relevant IDMO and administrative appeals to IDMO superiors need to be optimized. Filing objections and administrative appeals must be made before submitting a request for dispute resolution to the Information Commission. The Public Information Openness Act does not recognize administrative appeals. The Public Information Openness Act only recognizes objections raised by information applicants to IDMO superiors. There is an asynchronous term "objection" in this context. "Objection" should be submitted to the respondent (IDMO), whereas "objection to the PPID supervisor" should use the term "administrative appeal". Synchronization of terminology needs to be conducted, so that ambiguity does not occur in its implementation.

Second, the synchronization of Public Information Openness Act and Related Laws and Regulations. The dualism of pubic information settlement must be solved as fast as possible. Based on table 1 data regarding the number of public information disputes, it can be concluded that the disputing parties tend to use the Information Commission channel. The public begins to utilize the Information Commission in resolving public information disputes, before proceeding to the realm of the state administrative court.

The Public Information Openness Act indeed emphasizes optimizing the role of the Information Commission as an institution outside the court to resolve public information disputes. The Information Commission continues to carry out the function of resolving public information disputes through mediation and non-litigation adjudication. The parties who will continue their dispute to the court (state administrative court or general court) are required to settle disputes in the Information Commission (Central Information Commission, Provincial Information Commission, or Regency/City Information Commission). The mediation process is voluntary dispute settlement. It is used the Supreme Court Regulation No. 1 of 2008 that absolutely must be taken. Therefore, all cases must first be settled through mediation, as outlined in Article 2 paragraph (2) of the Supreme Court Regulation No. 1 of 2008 [14]. Mediation according to Mamudji, has the following characteristics: "advanced negotiations; assisted by neutral and impartial third parties; the third party does not have the authority to decide; the existence of third parties is accepted by the parties, and aims to resolve disputes based on satisfactory agreements" [15]. Article 1 number 6 of the Information Openness Act states: mediation is the settlement of public information disputes between the parties through the assistance of an information commission mediator.

The public information dispute settlement process at the Information Commission after mediation is a non-litigation adjudication. Article 1 number 7 of the Information Openness Act explains, "Adjudication is the process of resolving disputes over public information between parties decided by the Information Commission". The implementation of non-litigation adjudication resembles litigation, where the Information Commission seems to be like a judge who decides a dispute. This non-litigation adjudication decision has the same executorial power as the court's decision because, in its decision, it contains the words "For the Sake of Justice Based on The one and only God." It means that the decision of the Information Commission can already be executed without the need for a court decision.

Based on the case, non-litigation adjudication is a continuation of the mediation process. Both of these processes according to the opinion of the author must be taken before going through the judicial route. Out-of-court dispute resolution is needed to reduce the pile of unresolved cases in the Supreme Court.

\section{Discussion}

Public Information Openness Act needs to be synchronized with various relevant laws and regulations, such as; Government Administrative Act, Judicial Power Act, State Administrative Court Act, and the Supreme Court Act. Newly constructed construction requires the resolution of public information disputes through the Information Commission before being submitted to a district (general) court or state administrative court. The settlement of disputes through the court is an act of ultimum remedium (the last resort) [16].

The disputing party who has taken the path of mediation and non-litigation adjudication, if they are not satisfied, they can file a lawsuit or take the litigation to the district (general) court or state administrative court. In line with Article 47 paragraph (1) and (2) of the Public Information Openness Act, the filing of the lawsuit is carried out through a state administrative court if the sued person is the state public equivalent; and the filing of a lawsuit is carried out through a district (general) court if the sued 
person is a public body other than the state public body. With respect to the court's decision, the legal remedy that can be taken is to appeal to the Supreme Court. The exclusion of appeals from the litigation path is to fulfill a simple, fast and low-cost court process, as mandated by Article 2 paragraph (4) of the Judicial Power Act. In addition, because the parties to the dispute have taken the path of quasi litigation or non-litigation adjudication (a process resembling a court), there is no need to carry out further litigation processes after going through a district court or state administrative court process. The party who does not accept the decision of the state administrative court or the district (general) court can submit an appeal to the Supreme Court, whereas for judicial review as extraordinary legal efforts still follow the provisions in the Supreme Court Act.

In order to realize principles of justice that are simple, fast, and low-cost; it is necessary to regulate the grace period in the process of settling public information disputes through the Information Commission channel and the court line. Timing in arranging a dispute resolution is an effort to provide legal certainty for the parties to the dispute. The ideal time for dispute resolution in the mediation phase is a maximum of 10 working days; while the non-litigation adjudication stage is a maximum of 20 working days. The ideal time for dispute resolution through litigation (state administrative court or district/general court) is a maximum of 30 working days, while for the cassation stage a maximum of 60 working days.

Third, strengthening Information Commission. In the context of public information openness, The Information Commission has a very important role in the resolution of public information disputes. The ideal construction in resolving disputes over public information is to strengthen the institutional Information Commission as the foremost fortress in resolving public information dispute, outside of administrative-legal efforts (objections and administrative appeals). Speaking of strengthening the Information Commission, the problem of the independence of the Information Commission must be resolved immediately. This is in view of the quite strategic task, function, and authority of the Information Commission in implementing the Public Information Openness Act to ensure the fulfillment of the people's right to information as mandated by Article 23 juncto Article 26 of the PIO Act [17].

Institutional information rearrangement is absolutely necessary. A number of things need to be reorganized to strengthen the Information Commission's institution to become an independent and professional Information Commission, such as (1) Realizing the independence of the Central Information Commission and the Regional Information Commission. (2) Reformulation regarding the responsibility of the Information Commission. (3) Hierarchical or tiered institutional restructuring. (4) Additional duties, functions, and authority of the Information Commission.

Furthermore, the independence of the Central Information Commission can be started by reformulating the provisions of Article 29 paragraph (2) and (3) of the Public Information Openness Act which essentially states that the Information Commission secretariat is carried out by the government or led by a secretary established by the Minister. Regulation of the Minister of Communication and Information No. 11/PER/M.KOMINFO/03/2011 states that the secretariat of the Information Commission is attached to and under the Ministry of Communication and Information. This problem must be resolved, that is, to separate the Central Information Commission secretariat from the Ministry of Communication and Information. With the separation of the Central Information Commission secretariat from the Ministry of Communication and Information, it should have an impact on the existence of a separate budget heading of the Central Information Commission in the national budget [17]. This condition also occurs in the Regional Information Commission, whose secretariat is under the provincial, district, or city government.

Article 28 of the Public Information Openness Act regulates the responsibility of the Information Commission that is responsible to the executive (the Central Information Commission is responsible to the President, the Regional Information Commission is responsible to the Governor/Regent/Mayor). The provisions of Article 28 of the Public Information Openness Act contradict the context of Article 23 of the Public Information Openness Act that states that the Information Commission is an independent institution. The ideal construction is that the Information Commission submits a report to the executive, not to the executive. The ideal responsibility should be that the Regional Information Commission is responsible to the Central Information Commission, and the Central Information Commission is responsible in accordance with statutory regulations.

Article 24 paragraph (1) of the PIO Act defines the Information Commission as The Information Commission consists of the Central Information Commission, the Provincial Information Commission, and if a District/City Information Commission is needed. Furthermore, Prayitno et al., stated that normatively and empirically, there is no institution called the Information Commission, but there are the Central Information Commission, Provincial Information Commission, and Regency/City Information Commission [17]. To create an "Information Commission" agency, it must be conducted through the unification of the Central Information Commission, the Provincial Information Commission, and the Regency/City Information Commission in an institutional unit that is independent and hierarchical in terms of organizational, administrative and budget management aspects.

Construction of unification that assists the institutional Information Commission in stages ideally does not touch on aspects of resolving public information disputes. The dispute settlement model that has been designed at this time is still ideal to be maintained. This means that the resolution of information disputes at the Information Commission institution is not hierarchical or tiered. The verdicts that are produced are final and binding at each level, in the event that the disputing party does not file a lawsuit (not an objection as to the current PIO Act) to the court. Non-tiered information dispute resolution has goals that are as hard as dispute resolution that is carried out quickly, simply, and at a low cost.

One context of the implementation of the Public Information Openness Act that needs serious attention and often arises in resolving information disputes is the difficulty of executing the Information Commission's decision. This is because the Information Commission does not have the authority to execute decisions [17]. There is currently only the Information Commission mediation decision can be executed through the court, whereas the non-litigation adjudication decision of the Information Commission can't be requested for execution in court. Therefore, it is necessary to make a new construction 
related to the addition of duties, functions, and authority of the Information Commission, namely the granting of authority to execute the Information Commission's decision so that the Information Commission's decision is not blunt. Based on the description above, the new construction of ideal public information dispute resolution to realize substantive justice, as illustrated in Figure 2.

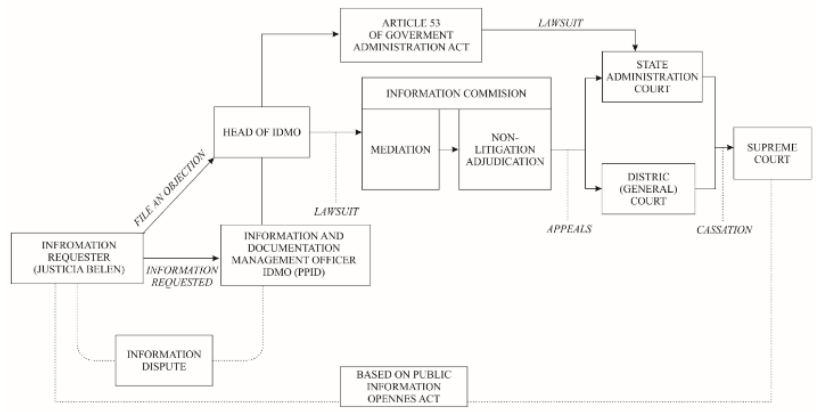

Figure 2. The New Construction of Information Dispute Settlement

\section{Conclusion}

The dualism in settlement of public information disputes in Indonesia arises because of the un-synchronization of the Government Administrative Act and the Public Information Openness Act. This problem must be resolved immediately to provide legal certainty related to the resolution of information disputes. The importance of resolving information disputes quickly because it relates to fulfilling a sense of justice for information applicants, fulfilling the right to information for the community, and building good governance in the administration of government, development, and public services.

New construction needs to be developed to find the best format for public information dispute resolution in Indonesia. The strengthening of the Information Commission as an independent institution that functions to run the Public Information Openness Act needs to be completed immediately. Ideally, information dispute resolution must be minimized to enter the court (litigation). It must strengthen resolution through administrative efforts and through the Information Commission. This is in line with the principle of fast, simple, and low-cost justice.

The independence of the Information Commission can no longer be postponed. It is necessary to separate the secretariat of the Information Commission from the executive. The Information Commission must also be independent in managing the budget, and institutional restructuring is also needed. In connection with the resolution of information disputes, the Information Commission needs to be authorized to carry out the information dispute decisions. Therefore, the parties comply with the decisions set by the Information Commission.

\section{Ethical issue}

Authors are aware of, and comply with, best practice in publication ethics specifically with regard to authorship (avoidance of guest authorship), dual submission, manipulation of figures, competing interests and compliance with policies on research ethics. Authors adhere to publication requirements that submitted work is original and has not been published elsewhere in any language.

\section{Competing interests}

The authors declare that there is no conflict of interest that would prejudice the impartiality of this scientific work.

\section{Authors' contribution}

All authors of this study have a complete contribution for data collection, data analyses and manuscript writing.

\section{References}

1. Wibawa, K. C. S. (2019). Urgensi Keterbukaan Informasi dalam Pelayanan Publik sebagai Upaya Mewujudkan Tata Kelola Pemerintahan yang Baik. Administrative Law \& Governance Journal, 2(2), 218-234.

2. Golwal, M. D., \& Kalbande, D. T. (2012). Right to Information Information Literacy and Public Libraries. Asia Pacific Journal of Management \& Entrepreneurship Research, 1(1), 89.

3. Fernandes, A. A. R., \& Fresly, J. (2017). Modeling of role of public leader, open government information and public service performance in Indonesia. Journal of Management Development.

4. Sjoraida, D. F., Husin, L. H., \& Mariana, D. (2018). Further analysis on freedom of information in Indonesia: A case study of public information disclosure in West Java Province. Journal of Social Research \& Policy, 9(1).

5. Utama, K. W., \& Sukmadewi, Y. D. (2019). Dualisme Penyelesaian Sengketa Permohonan Informasi Publik. Administrative Law \& Governance Journal, 2(4), 672-676.

6. Susanto, S. N., \& Wibawa, K. C. S. (2020). The Existence of The Indonesia Peatland Restoration Agency in Perspective of Organization and Authority. Administrative Law \& Governance Journal, 3(1), 92-103.

7. Subagiyo, H. (2009). Anotasi Undang-Undang Nomor 14 Tahun 2008 tentang Keterbukaan Informasi Publik. Jakarta: Komisi Informasi Pusat.

8. Kurniati, N. (2016). "Mediasi-Arbitrase" Untuk Penyelesaian Sengketa Tanah. Sosiohumaniora, 18(3), 197-207.

9. Thakore, D. (2013). Conflict and conflict management. IOSR Journal of Business and Management (IOSR-JBM), 8(6), 07-16.

10. Prasetyo, T. (2019). Penyelesaian Sengketa Keterbukaan Informasi Publik D1 Pengadilan Tata Usaha Negara Semarang. Jurnal Spektrum Hukum, 13(2), 238-261.

11. Creutzfeldt, N., \& Bradford, B. (2016). Dispute resolution outside of courts: procedural justice and decision acceptance among users of ombuds services in the UK. Law \& Society Review, 50(4), 985-1016.

12. Budiman, A. (2017). Penguatan keterbukaan informasi publik Majalah Info Singkat Hukum Kajian Singkat Terhadap Isu Akta, 9(8), 17-20. Available: http://www.lib.ui.ac.id/detail?id=20471787\&lokasi=lokal.

13. Hermanto, B., \& Sudiarawan, K. A. (2019). Rekonstruksi Pergeseran Paradigma Upaya Administratif Dalam Penyelesaian Sengketa Pra Pemilihan Kepala Daerah. Jurnal Legislasi Indonesia, 16(3), 325343

14. Bintoro, R. W. (2016). Kajian Ontologis Lembaga Mediasi di Pengadilan. Yuridika, 31(1), 121-142.

15. Mamudji, S. (2017). Mediasi Sebagai Alternatif Penyelesaian Sengketa di Luar Pengadilan. Jurnal Hukum \& Pembangunan, 34(3), 194-209.

16. Sufiarina, S., \& Fakhirah, E. L. (2014). Kewajiban Upaya Nonajudikasi Sebagai Syarat Mendaftarkan Gugatan Guna Mewujudkan Peradilan Sederhana, Cepat, dan Biaya Ringan (Tinjauan atas Perma No. 1 Tahun 2008). Padjadjaran Journal of Law, $1(1)$.

17. Prayitno, D.E., Hanafi, A. Setiawan, A., \& Samosir, D. (2015). Pembaharuan Komisi Informasi (Menuju Komisi Informasi Yang Mandiri Dan Profesional). Jakarta: Indonesian Parliamentary Center 